\title{
Effects of Pretreatment and Solid-State Fermentation on Tempeh Protein Content
}

\author{
DJUNARLIN TOJANG ${ }^{1}$, SAPARUDDIN SAPARUDDIN²*, \\ ALIMUDDIN ALIMUDDIN ${ }^{3}$ and ZUL ARHAM ${ }^{4 * *}$ \\ ${ }^{1}$ Agrotechnology Study Program, Faculty of Agriculture, Fisheries and Animal Husbandry, \\ Universitas Sembilanbelas November Kolaka, 93517, Southeast Sulawesi, Indonesia. \\ ${ }^{2}$ Biology Education Study Program, Faculty of Teacher Training and Education, Universitas \\ Sembilanbelas November Kolaka, 93517, Southeast Sulawesi, Indonesia. \\ ${ }^{3}$ Chemistry Education Study Program, Faculty of Teacher Training and Education, \\ Universitas Sembilanbelas November Kolaka, 93517, Southeast Sulawesi, Indonesia. \\ ${ }^{4}$ Department of Mathematics and Natural Sciences, Faculty of Tarbiyah, \\ Institut Agama Islam Negeri Kendari, 93563, Southeast Sulawesi, Indonesia. \\ *Corresponding authors E-mail: saparuddin.yadin@gmail.com, arhamzul88@yahoo.com
}

http://dx.doi.org/10.13005/ojc/370106

(Received: June 26, 2020; Accepted: January 20, 2021)

ABSTRACT

In this study the effect of pretreatment and solid-state fermentation (SSF) on Tempeh protein content has been studied. Pretreatment and SSF are important processes for producing high-quality Tempeh. Based on the results of the analysis using a UV-Vis spectrophotometer at $\lambda_{\max }=540 \mathrm{~nm}$, it is known that both pretreatment and SSF cause the reduced Tempeh protein content. Pretreatment causes the total protein content $(\mathrm{w} / \mathrm{w}$ ) to decrease rapidly from $1.05 \%$ to $0.82 \%$, while the SSF causes the content dissolved protein $(\mathrm{w} / \mathrm{w})$ reduced from $0.57 \%$ to $0.11 \%$. In addition, SSF increased the Tempeh $\mathrm{pH}$ from 4.67 to 5.65 and decreased the water content (\%) from 6.38 to 2.04 .

Keywords: Tempeh, Pretreatment, Solid-state fermentation, Protein content.

\section{INTRODUCTION}

Tempeh is a traditional Indonesian food that is produced through the process of soybean fermentation using Rhizopus $\mathrm{sp}^{1,2,3}$. Tempeh attracts many people not only in Indonesia, but also at this time it is reportedly consumed by people in several countries. Tempeh has a special taste and several benefits to the human body have been reported such as inhibiting the biosynthesis of cholesterol in the liver, preventing LDL oxidation, increasing the antioxidant SOD enzyme, reducing the risk of rectal, prostate and breast cancer, reducing total cholesterol and triacylglycerol ${ }^{4,5}$.

The use of soybeans as the main raw material for making Tempeh is based on its high protein content composed of various types of amino acids ${ }^{6}$. Protein is reported as an important parameter in explaining the quality of Tempeh. In this case, the

This is an Open Access article licensed under a Creative Commons license: Attribution 4.0 International (CC- BY). Published by Oriental Scientific Publishing Company @ 2018

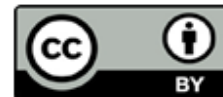


Indonesian National Standardization Agency (BSN) No. 3144 of 2012 stipulates that the minimum protein content in Tempeh is $16 \%(w / w)^{7}$. In the acquisition of protein levels, the manufacturing process becomes a determining factor in the availability of protein ${ }^{8}$. In general the process of making Tempeh consists of two important stages, namely raw material pretreatment and fermentation. Several stages of pretreatment are carried out during the process of making soybean Tempeh including boiling, grinding, washing, soaking, and steaming. In the boiling and steaming stages, it is usually done at high temperature conditions so that it will have an impact on the availability of protein ${ }^{9}$. As with the pretreatment process, the fermentation process is also reported to affect the availability of the amount of protein ${ }^{10}$. The presence of protease enzymes formed during the fermentation process will gradually denaturate proteins ${ }^{11}$.

This study was conducted to determine the effect of the pretreatment and solid-state fermentation (SSF) processes on the amount of Tempeh protein. Although research on Tempeh has been widely reported, it has not specifically reported the effect of the manufacturing process on the content of tempeh protein. Information about changes in protein content during the process of making Tempeh needs to be known, because in the last year Tempeh was not only consumed directly by the community, but tempeh was also used as an alternative food additive to increase the nutritional value of coconut milk sauce ${ }^{12}$.

\section{MATERIALS AND METHODS}

\section{Making Tempeh}

Soybeans washed and then boiled for \pm 60 minutes. Furthermore, soaked for \pm 720 minutes. After soaking, the soybean epidermis is peeled and washed then steamed for 45 minutes. The soybean seeds are then drained, after being cold added Rhizopus sp. Where every $2 \mathrm{~g}$ Rhizopus sp. homogeneously mixed into $1 \mathrm{~kg}$ of soy beans. Furthermore, it is wrapped in plastic and incubated at room temperature for 1 day, 2 days, 3 days, 4 days, and 5 days, respectively.

\section{Analysis of protein content Sample preparation}

Tempeh with different fermentation times (1-5 days) is dried in an oven at $80^{\circ} \mathrm{C}$ for 24 hours. then mashed and filtered using a sieve with a pore size of $\pm 0.3 \mathrm{~mm}$.

\section{Total Protein Levels}

A total of $0.50 \mathrm{~g}$ of the tempeh was added to the destruction flask and $10 \mathrm{~mL}$ of concentrated $\mathrm{H}_{2} \mathrm{SO}_{4}$ was added. Then it is destructed until all the samples in the destruction flask dissolve and the liquid becomes clear greenish. After the digestion process is complete, the solution is left for a while to cool. Furthermore as much as $1.0 \mathrm{~mL}$ of the digestive solution was taken and the biuret reagent was added as much as $3.0 \mathrm{~mL}$. Then stirred at vortex and incubated at room temperature for 30 minutes. Then absorbance was measured at a maximum wavelength $\left(\lambda_{\max }\right)$ of $540 \mathrm{~nm}$ using a UV-Vis spectrophotometer.

\section{Dissolved Protein Levels}

A total of $1.0 \mathrm{~g}$ of the Tempeh was dissolved with $50 \mathrm{~mL}$ phosphate buffer $\mathrm{pH} 8$ and stirred with a magnetic stirrer. Then the mixture was centrifuged and filtered using filter paper. The obtained filtrate was transferred into a $50 \mathrm{~mL}$ measuring flask, then a phosphate buffer $\mathrm{pH} 8$ was added to the limit mark. The filtrate was taken $1.0 \mathrm{~mL}$, then a $3.0 \mathrm{~mL}$ biuret reagent was added. Stir in the vortex and incubate at room temperature for 30 minutes. Then the absorbance was measured at the maximum wavelength $\left(\lambda_{\max }\right)$ of 540 $\mathrm{nm}$ using a UV-Vis spectrophotometer.

\section{$\mathrm{pH}$ analysis}

A total of $5.0 \mathrm{~g}$ of the Tempeh was mixed with $10 \mathrm{~mL}$ of distilled water (comparison of sample and distilled water ie 1:2). The mixture was then stirred using a magnetic stirrer for 30 minutes. The $\mathrm{pH}$ of the subsequent sample was measured using a $\mathrm{pH}$ meter.

\section{Water content analysis}

A total of $2.0 \mathrm{~g}$ of the Tempeh is dried in the oven for 1 hour. Cooled in a desiccator, then weighed dry weight. The treatment is repeated until a constant weight is obtained, then the water content is calculated.

Water content $=\frac{(\mathrm{w} 1-\mathrm{w} 2)}{\mathrm{w} 2} \times 100$

Notes:

$\mathrm{w} 1$ = Weight of sample before drying (g)

w2 = Weight of sample after drying $(\mathrm{g})$

\section{RESULTS AND DISCUSSION}

Effect of pretreatment of tempeh raw materials Figure $1 \mathrm{~A}$ shows the effect of the 
pretreatment process on both total and dissolved soy protein content. Pretreatment- 1 is a process of boiling, grinding, washing and soaking. While pretreatment-2 is a steaming process, this process is the final process of soybean pretreatment before the addition of Rhizopus sp. The final pretreatment process generally causes a decrease in total and dissolved soy protein content. The effect of pretreatment on soluble protein (black line) shows that there is an increase in the amount of dissolved protein during pretreatment- 1 and gradually decreases significantly during pretreatment-2. While the total protein (blue line) shows that the pretreatment process gradually causes protein denaturation.

Figure 1B shows the effect of pretreatment temperature on the amount of dissolved protein in soybean raw material. The amount of dissolved protein increases linearly with increasing temperature. However, the use of higher temperatures causes a decrease in dissolved protein content. This can also be seen in Fig. 1A, where in the process of steaming (pretreatment-2) there is a significant decrease in dissolved protein content. So the use of pretreatment temperature becomes an important parameter to get good raw materials in making tempeh.
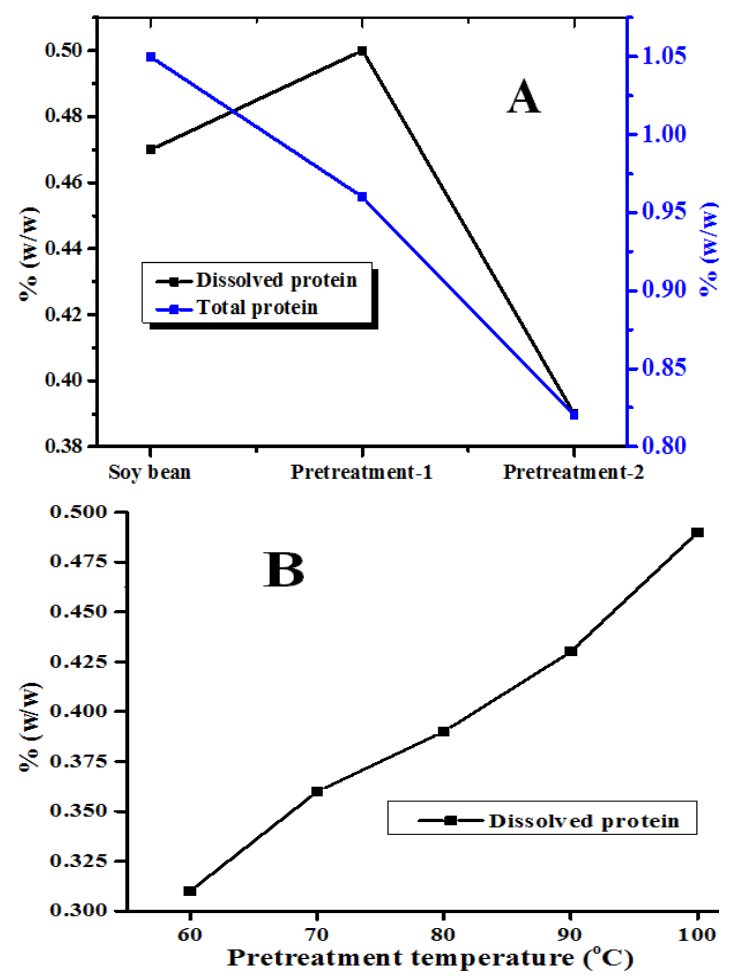

Fig. 1. (A) Effect of pretreatment on protein content; (B) Effect of temperature pretreatment on dissolved proteins

\section{Effect of Solid-State Fermentation (SSF) on tempeh protein}

Figure 2 shows the effect of SSF time on the protein content of both protein total (blue line) and dissolved protein (black line). The long SSF time causes the total protein content in tempeh to increase while the dissolved protein content decreases. Increased total protein associated with the number of mycelia Rhizopus sp. which gets more and more as SSF time increases. Rhizopus sp. contributed significantly to the total protein content, where the structure of Rhizopus sp. which are composed of chitin will contribute to the presence of nitrogen groups. In addition, during the SSF process, Rhizopus $s p$. also produce protein. As for the decrease in dissolved protein content, it can be associated with the activity of Rhizopus sp. which denature tempeh proteins into amino acids and short chain peptides, and the formation of $\mathrm{NH}_{3}$ due to Tempeh decay.

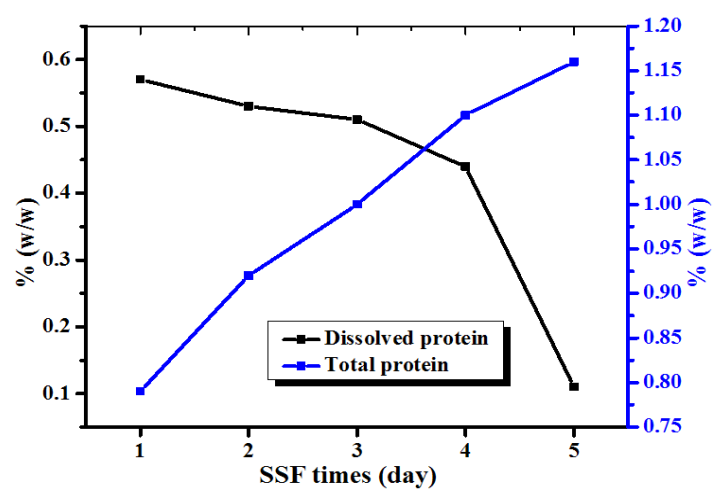

Fig. 2. Effect of SSF times on the content of Tempeh protein

Besides the protein content, the time of SSF also affects the acidity $(\mathrm{pH})$ and the water content of tempeh. The influence of SSF time on $\mathrm{pH}$ is shown in Fig. 3, where the SSF time gradually causes the $\mathrm{pH}$ of the Tempeh to be higher near neutral $\mathrm{pH}(\mathrm{pH}$ $=7.0$ ). This characteristic correlates with the amount of denatured protein ${ }^{13}$ and decreased activity of Rhizopus sp. ${ }^{14,15,16}$. The increase in $\mathrm{pH}$ is also related to the formation of free amino acids. ${ }^{17}$

Figure 4 shows the effect of the SSF time on the Tempeh content. Water content decreases linearly with the length of time the SSF. The decrease in water content can be attributed to the reduction in the amount of dissolved protein and damage to the hydrogen bonds either formed between the amide group with water or amide groups with other amide groups. Another factor that causes a decrease in water content is the activity 
of microorganisms that damage starch components thereby reducing $\mathrm{OH}$ bonds in its structure ${ }^{18}$.

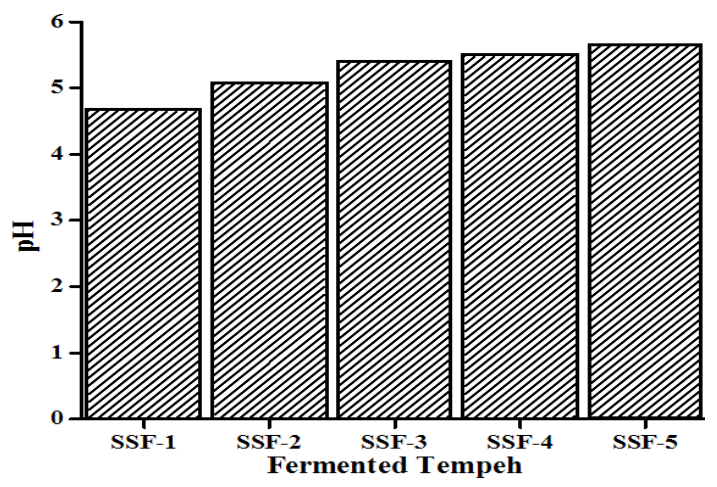

Fig. 3. Effect of SSF time on $\mathrm{pH}$ of Tempeh

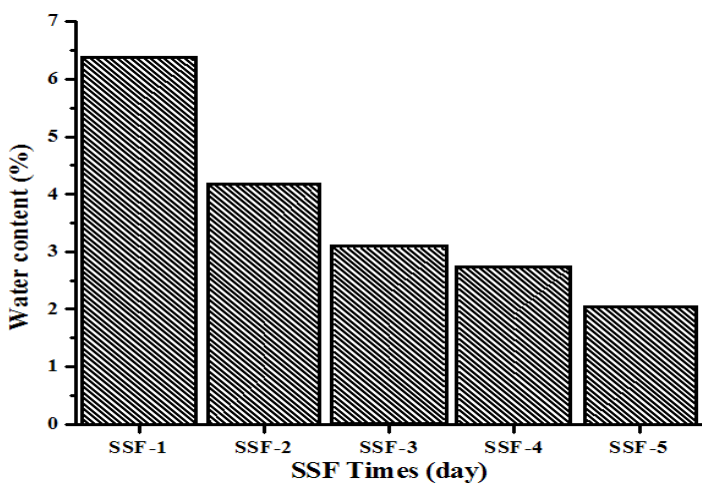

Fig. 4. Effect of SSF time on Tempeh water content

\section{FTIR Analysis}

Reduction of the amount of Tempeh protein both during the pretreatment and fermentation processes was also observed based on the IR uptake of the protein building blocks. Based on its structure, proteins are composed of amino acids linked by amide bonds. This bond consists of groups $\mathrm{C}=\mathrm{O}$ and $\mathrm{N}-\mathrm{H}$ with specific IR absorption that occurs at wave numbers in a row that is $1700 \mathrm{~cm}^{-1}$ and 1550 $\mathrm{cm}^{-1}{ }^{19,20}$. Fig. 5 shows the IR spectra of test samples before pretreatment (soybean), after pretreatment, and after fermentation (Tempeh). The fundamental difference is seen in the absorption intensity for wave numbers $1700 \mathrm{~cm}^{-1}$ and $1550 \mathrm{~cm}^{-1}$. The magnitude of the absorption intensity correlates with the amount of protein contained in the test sample. Soybean samples (Orange line) show the intensity of specific IR uptake for protein is greater than the intensity of specific IR uptake of samples after pretreatment (Red line) and fermentation (Blue line). This reinforces information about protein denaturation both during the pretreatment process and during fermentation.

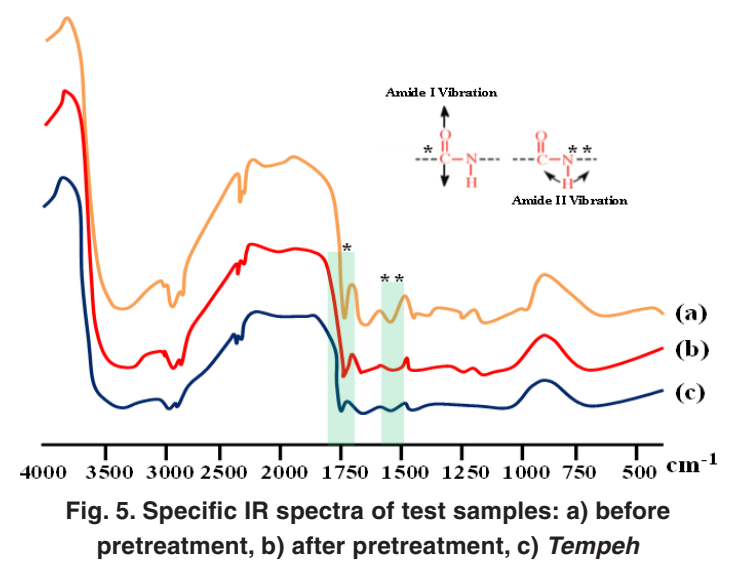

CONCLUSION

The process of making soybean Tempeh in general consists of two important stages, namely the pretreatment and solid-state fermentation processes. Based on the results of this study, both processes affect the content of Tempeh protein. Where pretreatment temperature and fermentation time are the main factors in decreasing and increasing the protein content. The use of high pretreatment temperatures causes both total protein and dissolved protein to gradually denaturate. So is the case with the fermentation process.

\section{ACKNOWLEDGEMENT}

Authors acknowledge the financial support of the Research Institutions and Community Service, Universitas Sembilanbelas November Kolaka, Indonesia.

\section{Conflict of Interests}

We declare that we have no competing financial interests or personal relationships that could affect the work we report in this paper.

\section{REFERENCES}

1. Hartanti; Tatik, A.; Rahayu, G.; Hidayat, I. HAYATI Journal of Biosciences., 2015, 22(3), 136-42.

2. Lu, H.; Huang, Z.; Zhang, Y.; Zhou, S.; Hu, W.;
Dong, M. LWT., 2019, 111, 694-702.

3. Kurniawati; Syukria; Lestiani, D. D.; Damastuti, E.; Santoso, M. Journal of Food Composition and Analysis., 2019. 
4. Chan, Yin-Ching, I. Te Lee, Ming-Fu Wang, Wen-Chin Yeh, and Bi-Chun Liang. Journal of Functional Foods., 2018, 50, 112-19.

5. Tahir; Arifa; Anwar, M.; Mubeen, H.; Raza, S. Journal of Advances in Biology \& Biotechnology., 2018, 1-9.

6. Reyes-Moreno, C.; C. Romero-Urias, J.; Milán-Carrillo, B.; Valdez-Torres.; E. ZárateMárquez. Plant Foods for Human Nutrition., 2000, 55(3), 219-28.

7. Badan Standardisasi Nasional (BSN)., Jakarta: Badan Standardisasi Nasional 2, 2012.

8. Schön, Arne, Clarkson, B. R.; Jaime, M.; Freire, E. Proteins: Structure, Function, and Bioinformatics., 2017, 85(11), 9-16.

9. Tao; Xia; Cai, Y.; Liu, T.; Long, Z.; Huang, L.; Deng, D.; Zhao, Q.; Zhao, M. Food Hydrocolloids., 2019, 90, 394-402.

10. Setiawan, J.; Giyarto, D. Agriculture and Agricultural Science Procedia., 2016, 9, 342-47.

11. Tri, H.; Naofumi, Morita. International Journal of Food Properties., 2006, 9(2), 347-55.

12. Cook, Paul, E. Food Research International., 1994, 27(3), 309-316.

13. Wolkers-Rooijackers, Judith, C. M.; Martha F. E.; Eddy, J. S. LWT., 2018, 96, 513-518.

14. Feng.; Xin, M.; Thomas, O. L.; Johan, S. International Journal of Food Microbiology., 2007, 113(2), 133-41.

15. Yin, H.; Feng, J.; Jin, H. Grain \& Oil Science and Technology., 2019, $X X, \mathrm{xx}-\mathrm{xx}$.

16. Nowak, J.; K. Szebiotko. Food Microbiology., 1992, 9(1), 37-43.

17. Churchill, H.; Henry, T.; Robert, M. H. American Mineralogist., 2004, 89(7), 1048-55.

18. Frediansyah, A.; Muhamad, K. Nusantara Bioscience., 2016, 8(2), 207-14.

19. Depciuch, J.; Magdalena, S. K.; Gabriel, N.; Dominika, D.; Marcin, S.; Krzysztof, S.; Magdalena, P.W. Journal of Pharmaceutical and Biomedical Analysis., 2016, 131, 287-96.

20. Kaur, J.; Shalmoli, B. Biophysical Journal., 2019, 116(3), 57a-58a. 